\title{
UCLA director gets the goods as California makes good on its stem cell initiative
}

Tres.

he $\$ 3$ billion California stem cell initiative has finally awarded its first set of grants. The granting agency, the California Institute for Regenerative Medicine (CIRM), allocated a total of nearly $\$ 40$ million to 16 California institutions with the goal of creating a stem cell training program for predoctoral, postdoctoral, and clinical fellows. The largest award, \$3.75 million, went to UCLA.

The JCI spoke to Owen Witte, professor and director of the UCLA Institute for Stem Cell Biology and Medicine, about his plans for this money, his own work, and how UCLA was so successful in attaining this large award.

JCI: Your institute was just awarded the largest grant of the first round of stem cell

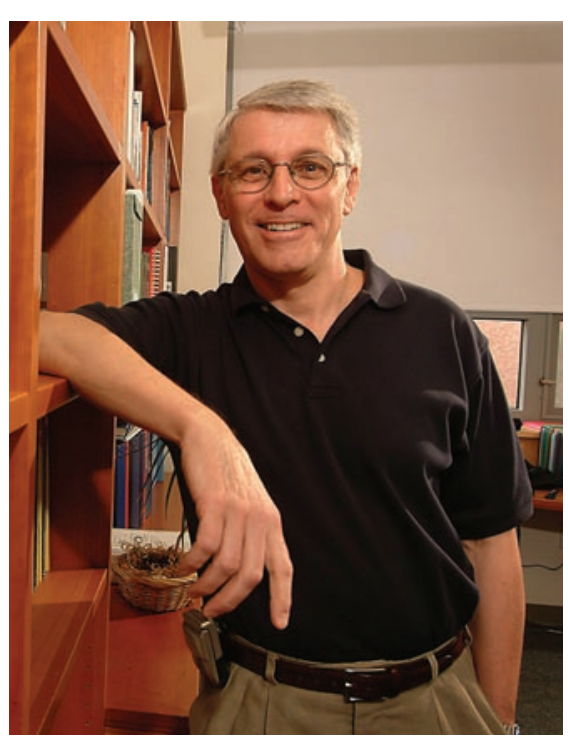

Owen Witte, director of the UCLA Institute for Stem Cell Biology and Medicine. research grants from the state of California. What exactly is this money going to be used for?

Witte: These funds will support the salaries of 5 graduate students, 5 postdoctoral fellows, and 6 clinical fellows. The term of the grant is 3 years.

JCI: What was the focus of your grant application?

Witte: We cover many aspects of biomedical research and stem cells, but our particular areas of strength are cancer, HIV/ AIDS, and neurological diseases. We also have a broad campus with social sciences and law represented, and they interface with stem cell issues.

JCI: Why do you think your application was so successful?

Witte: We received high marks for the breadth of our science and clear institutional commitment, which includes 12 new faculty positions to help staff the institute and a very strong program in cell transplantation research and clinical trials including a GMP-certified cell processing center. This facility is FDA and state of California certified. We also have a solid track record in translational medicine - our research has led to the development of drugs like Gleevec and Herceptin.

JCI: What are the main goals of the stem cell research programs at UCLA?

Witte: To provide continuity of basic research into translational medicine to improve the treatment of human disease.

JCI: What does your lab study?

Witte: My group studies hematopoetic stem cells and their relation to the devel- opment of human leukemias as well as the nature of the prostate stem cell and how it is related to the progression of epithelial cancers of that gland.

JCI: What do you consider the most impressive findings in stem cell research thus far?

Witte: The nuclear transplantation experiments [by Woo Suk Hwang's group] in Korea have opened up a world of future therapeutic possibilities.

JCI: What do you think the future of stem cell medicine holds, both scientifically and politically?

Witte: It's a tough question to answer specifically, but even in the face of constant political and social concerns, the science has been moving forward in the US and around the globe. I'm impressed with the progress so far.

JCI: How did you become interested in stem cell research?

Witte: It's directly connected to my main area of interest in understanding cancer causation and progression.

JCI: What do you consider to be your greatest scientific accomplishment?

Witte: My work defining tyrosine kinase involvement in human diseases like ABL in murine leukemias and BCR-ABL in human chronic myelogenous leukemia, and Bruton's tyrosine kinase in human X-linked agammaglobulinemia.

JCI: And your greatest accomplishment outside the lab?

Witte: Training and mentoring future scientists.

\section{Stacie Bloom}

\section{Displaced docs and researchers ride out the storm}

$\mathrm{T}$ he storm is over, but research universities in Katrina-ravaged areas along the Gulf Coast are still struggling to regroup. The hurricane caused scientists to spread out in search of temporary homes and laboratories and led to the loss of countless hours of scientific research.
Although many facilities themselves remain standing, the data that was at their heart has been destroyed, and with it the cell lines, tissue samples, transgenic animals, and reagents needed to start experiments back up again. Precious samples collected over years from patients with specific diseases are gone.
"Our laboratories have been without power since the hurricane," said Nicolas Bazan, head of Louisiana State University's (LSU's) Neuroscience Center of Excellence. "I am very concerned about equipment and reagents that will not be able to withstand the high temperatures and humidity of New Orleans 